\title{
Development of Economy of the Republic of Serbia through Processing less Hazardous Waste into Useful Products, the Case of Compost
}

\author{
Slobodan POPOVIĆ ${ }^{*}$, Biljana MARTINOVIĆ ${ }^{2}$, Aleksandar MAJSTOROVIĆ ${ }^{3}$, \\ Milan UGRINOVIĆ ${ }^{4}$, Ratko GARIĆ ${ }^{5}$ \\ ${ }^{1}$ JKP Gradsko Zelenilo Novi Sad, Sutjeska No. 2, 21000 Novi Sad, Serbia \\ ${ }^{2}$ Blood Transfusion Institute of Serbia, 11000, Belgrade, Serbia \\ ${ }^{3}$ Union Nikola Tesla Belgrade, Faculty of Real Estate Management, 11000 Belgrade, Serbia \\ ${ }^{4}$ Institute for Vegetable Crops, Karađorđeva No. 71, 11420 Smederevska Palanka, Serbia, \\ ${ }^{5}$ Centre for Civil Society Development in BiH, 74000, Doboj, BiH \\ * corresponding author: slobodan.popovic49@gmail.com \\ Bulletin USAMV series Agriculture 72(1)/2015 \\ Print ISSN 1843-5246; Electronic ISSN 1843-5386 \\ DOI 10.15835/buasvmcn-agr: 11029
}

\begin{abstract}
Observation of waste, in recent decades, should be conducted multidisciplinary, i.e. it is the subject of several scientific disciplines, such as economics, ecology, agriculture, industry, which will produce a new system of processing and more. Generally, the waste is viewed as an object or substance which the owner wants to postpone or reject. Green Economy, treated useful waste, by means of environmental reasons, but also through the potential opportunities of development, especially the recycling industry. By processing only $10 \%$ of plant and animal waste into compost the state of Serbia can save about 6:54 million $€$, because that amount does not have to give to import compost, but itself can produce and return to the ecosystem.
\end{abstract}

Keywords: useful waste, economic development, compost.

\section{INTRODUCTION}

Countries that want development have to learn how to use their natural resources in a wise and sustainable manner. This means the transition to a green economy as the basis of the philosophy of observation economy, agribusiness, processing of waste and the other in useful products. In all industries and in the whole economy, planning represents the primary phase of the process management (Williams, 2010), while quickly adapting market environment. In the last decade in the Republic of Serbia, an increasing number of research including socio-economic observation (Popović, 2014), and there are more and more studies involving ecological and economic situations (Popović et al., 2014), which can have a positive impact on the economy of a state and beyond. Such surveys are increasingly common as Serbia has been going accelerated steps towards the EU.

\section{AIMS AND OBJECTIVES}

The aim of this study is to emphasize the creation of a constant amount of different categories of waste in the Republic of Serbia, which is deposited in landfills in the Republic of Serbia to the continued existence of the cost of the deposit of all taxpayers in Serbia. Processing of waste, but not to unnecessary and irrational filling the dumps, it could be created a larger number of products that can be restored to nature, which will exert positive effects on the environment and the flora and fauna. Therefore, the aim of the research, after awakening public awareness of science, there 
Tab. 1. Total waste generated by groups of waste, EWC-STAT in the Republic of Serbia for the period 2011-2013, in tons.

\begin{tabular}{cccc}
\hline $\begin{array}{c}\text { Groups of waste according to } \\
\text { the EWC-STAT }\end{array}$ & 2011 & 2012 & 2013 \\
\hline Mineral and Waste & 48.526 .538 & 54.329 .800 & 57.722 .067 \\
\hline The chemical and medical waste & 61.928 & 62.957 & 90.528 \\
\hline Waste recycling & 155.908 & 273.277 & 338.164 \\
\hline The animal and vegetable waste & 201.765 & 177.480 & 96.158 \\
\hline Mixed waste & 50.422 & 177.363 & 136.109 \\
\hline Sludge & 681 & 1.891 & 3.480 \\
\hline Electronic Equipment & 4.131 & 9.960 & 4.145 \\
\hline Total & 49.001 .373 & 55.032 .727 & 58.390 .651 \\
\hline Source: Author's calculations based on the Statistical Yearbook of the Republic of Serbia for 2014. &
\end{tabular}

could be created a different and more organized way of managing less dangerous plant and animal waste. Of such waste, there could be made products that can have their market measurable value. The authors, in this paper, point to the importance of processing less dangerous waste into compost.

\section{MATERIALS AND METHODS}

During the preparation, this paper was based on publicly available data of the Statistical Office of the Republic of Serbia, which was carried out in accordance with international standards and recommendations made by adopting European Parliament No 2150/2002 of the European Parliament on waste statistics. In table 1 , the authors presented by main categories an overview of the total waste generated in the Republic of Serbia for the period 2011-2013.

\section{RESULTS AND DISCUSSIONS}

A large part of the amount of different categories of waste, which the authors have shown in Table 1, can be used and industrially processed into useful products. Such products can be sold on the market, and that confirms the social responsibility of a state towards the ecology, industry, retail sector, and population that on the basis of better organization can enjoy the benefits of a green economy.

All the products by recycling have their value. If we do not produce in the territory of the state, that products have to be imported, while slaughter industry as well as vegetable waste has to be generated in a certain area to be deposited, noting that for the delay must allocate funds. The authors give an overview of generated waste by groups in the Republic of Serbia for the period 2011-2013 expressed in tons, based on officially published data of the Statistical Office of the Republic of Serbia (webrzs.stat.gov.rs), in order to professional public had access to the actual quantities of waste generated in Serbia per year.

\section{CONCLUSION}

At the end, the authors emphasize that the processing of only $10 \%$ less dangerous plant and animal waste into compost, it is possible evaluation of compost at retail prices from January 2015.

Serbia expressed in the amount of about 6.54 million $€$. Instead of burying at the landfill such a product could be right back in the land, which would in the long run economic effects on the environment and humans were much higher than shown and calculated values of compost, which the authors showed.

\section{REFERENCES}

1. Popović S (2014). Socio-ekonomski faktori ograničenja razvoja agrara, Novi Sad, Feljton 30.

2. Popović S, Tošković J, Grublješić Ž (2014). EnvironmentalEconomic Model of Developing Composters in Parks, Protected Areas and City Limits in the Republic of Serbia, ProEnvironment 7:213-217.

3. Williams C (2010). Principi menadžmenta, Beograd, Data Status: 76

4. ** http://webrzs.stat.gov.rs/WebSite/Public/PageView. aspx?pKey $=82$ 